\title{
Integrated Service Quality Analysis Towards Performance of Employee Agency Integrated One Door Services (BPTSP) in DKI Jakarta With Customer Satisfaction as an Intervening Variable
}

\author{
Sri Kartika Sari Antariksa* \\ STIE Bisnis Indonesia \\ Jakarta, Indonesia \\ *kartikaantariksa2004@gmail.com
}

\begin{abstract}
The purpose of this research is to investigate the influence of service quality, customer satisfaction, service quality to employee performance in BPTSP DKI Jakarta. The sample of this study as many as $\mathbf{3 0 0}$ respondents. Data processing method, using SEM technique. The type of data in this study is qualitative data generated through survey results of the communities currently in the One Stop Integrated Service Agency with Competency Scale, Power Response, Guarantees, Empathy, Physical Evidence on Employee Performance One Stop Service Centre (BPTSP) In DKI Jakarta with Customer Satisfaction Being Intervening Variable. The result of research with hypothesis test obtained as follows: Reliability has positive and significant impact on customer satisfaction. Responsiveness does not have a positive effect on customer satisfaction BPTSP DKI Jakarta. Guaranteed positive impact on customer satisfaction BPTSP DKI Jakarta. Empathy does not have a positive impact on customer satisfaction (society) of BPTSP DKI Jakarta. Physical evidence does not have a positive impact on customer satisfaction BPTSP DKI Jakarta. Reliability has a positive impact on the performance of Jakarta BPTSP. Responsiveness does not have a positive impact on the performance of Jakarta BPTSP. Guaranteed positive impact on the performance of Jakarta BPTSP. Empathy does not have a positive impact on the performance of Jakarta BPTSP. Physical evidence has no positive and significant impact on Jakarta BPTSP. customer satisfaction has a positive impact on the performance of BPTSP DKI Jakarta.
\end{abstract}

Keywords-reliability, responsiveness, assurance, empathy, physical evidence, employee performance, public satisfaction

\section{INTRODUCTION}

The government has carried out bureaucratic reforms in all fields, namely improvements and improvements reflected in changes as a commitment to create a situation that is better than the original state. Internal reform of the bureaucrat or government is an important decision, not only for government employees but also for the nation and state and national interests in general. Bureaucracy is defined as an organized arrangement to achieve administrative tasks by systematically coordinating the work of many people. Bureaucratic reform, among others, makes the system of governance more effective and efficient, with faster, more transparent and accountable time, including in perfecting permits through simplifying legal licensing.

Poor licensing governance such as difficult, long-term and expensive business licensing will result in the reluctance of business operators to take care of licensing and hinder the growth of new business activities. In fact, without ownership of a business permit, a business entity/ individual is very difficult or even unable to carry out investment activities legally, and it is very difficult to borrow capital from financial/ banking institutions which always require licensing administrative documents such as notarial legality (notary deed), SIUP (Trading Business License), TDP (Company Registration Certificate).

On bureaucratic reform which refers to the contents of Perpres No. 54 of 2012 concerning the 2013 Government Work Plan, places the matter of improving the business climate as a strategic issue in increasing competitiveness. In addition, to the investment realization target of $11 \%$ in 2013 , the government specifically determined to summarize the starting a business nationally from 45 days (2011), 36 days (2012) to 20 days in 2013. Business Licensing as a core element in the phase of starting a business in this country, became the main target of reform. All licensing and non-licensing processes to the One Stop Integrated Service Agency (BPTSP).

\section{LITERATURE REVIEW}

\section{A. Service Quality}

Zetihaml et al [1] introduces 10 dimensions of Service Quality that are commonly used in measuring quality, namely reliability, responsiveness, competence, courtesy, credibility, security, access, communication, understanding the customer, 
tangible. From the ten dimensions of quality above can be summarized in 5 dimensions of service quality, namely: 1) Reliability is the ability to prove reliable and accurate service promises such as timeliness, the same service for customers without error sympathetic attitude with high accuracy, 2) Responsiveness is the willingness to help and provide fast and appropriate service to customers, by delivering clear information, 3) Assurance is the knowledge, politeness, and ability of employees to foster customer confidence in the company, 4) Empathy is giving sincere and individual or personal attention given to customers by trying to understand the desires of consumers, and 5) Tangible (direct evidence) is something that can be seen, physical evidence, building equipment, and equipment with high technology.

\section{B. Total Quality Service}

There are 5 Total Quality Service (TQS) focuses: Focus on the customer. Optimizing service quality by identifying the needs, desires and expectations of consumers, as well as planning the design of certain services to consumers [2]. In identifying the need to develop a partnership system with consumers and suppliers based on the principle of mutual benefit of both parties [3]. Total involvement, total involvement means commitment. Management must provide opportunities for service improvement for each employee and management demonstrates leadership quality throughout the organization. Management needs to delegate responsibility and authority to improve work processes for those who actually work; Measurement, internal / external measurements of the organization and customers include: a. Measurement and development of processes and results. b. Identify the outputs of important work processes according to customer requirements. c. Correcting and correcting yourself when something goes wrong at work, without having to wait for instructions from a higher level; Systematic support, management is responsible for building quality infrastructure into internal management structures and connecting quality with existing management systems such as strategic planning, performance management, awards, rewards, and promotions. and communication; Continuous improvement in continuous improvement, each individual is responsible for looking at work as a process, anticipating changes in needs, desires, and expectations of customers, and others.

\section{Customer Satisfaction}

Consumer satisfaction is the attitude of like or dislike consumers after they buy or use products (goods and services $[2,4]$. Customer satisfaction is the standard in assessing the success of an organization's achievement through performance [5]. Customer satisfaction is a function of views on product or service performance and consumer expectations [6].

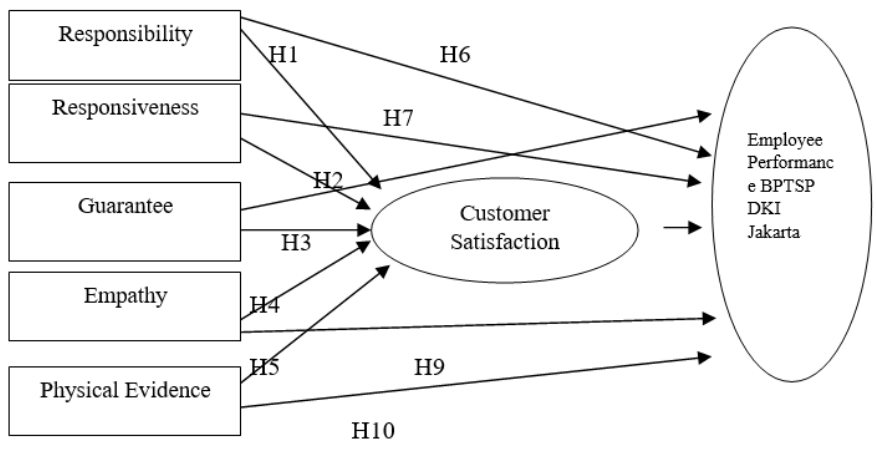

Fig. 1. Conceptual framework

\section{METHODS}

The sample of this study as many as 300 respondents.

- Customer Satisfaction $=£+\beta 1$ Realibity + $\beta 2$ Responsiveness $+\beta 3$ Guarantee $+\beta 4$ Emphaty + $\beta 5$ Physical Evidence $+\sum$

- Customer Satisfaction $=£+\beta 1$ Employee Performance + $\sum$..

- Employee Performance $=£+\beta 1$ Realibity + $\beta 2$ Responsiveness $+\beta 3$ Guarantee $+\beta 4$ Emphaty + $\beta 5$ Physical Evidence $+\sum$.

All of the result from validity and reliability is valid, it is showed as follow:

TABLE I. VALIDITY AND RELIABILITY RELIABILITY (X1)

\begin{tabular}{|c|l|c|}
\hline Item & Pearson Correlation & Alpha \\
\hline $\mathrm{X} 1.1$ & 0.716 & 0.775 \\
\hline $\mathrm{X} 1.2$ & 0.481 & 0.775 \\
\hline $\mathrm{X} 1.3$ & 0.802 & 0.775 \\
\hline $\mathrm{X} 1.4$ & 0.756 & 0.775 \\
\hline \multicolumn{2}{|c|}{ Sources: data processed }
\end{tabular}

TABLE II. VALIDITY AND RELIABILITY RESPONSIVENESS (X2)

\begin{tabular}{|c|l|c|}
\hline Item & Pearson Correlation & Alpha \\
\hline X2.1 & 0.559 & 0.795 \\
\hline X2.2 & 0.790 & 0.795 \\
\hline X2.3 & 0.825 & 0.795 \\
\hline X2.4 & 0.787 & 0.795 \\
\hline \multicolumn{2}{|c|}{ Sources: data processed } \\
\hline
\end{tabular}

TABLE III. VALIDITY AND RELIABILITY GUARANTEE (X3)

\begin{tabular}{|c|c|c|}
\hline Item & Pearson Correlation & Alpha \\
\hline X3.1 & 0.543 & 0.803 \\
\hline X3.2 & 0.820 & 0.803 \\
\hline X3.3 & 0.868 & 0.803 \\
\hline X3.4 & 0.817 & 0.803 \\
\hline \multicolumn{2}{|c|}{} \\
\hline
\end{tabular}


TABLE IV. V VALIDITY AND RELIABILITY EMPATHY (X4)

\begin{tabular}{|l|l|c|}
\hline Item & Pearson Correlation & Alpha \\
\hline X4.1 & 0.529 & 0.801 \\
\hline X4.2 & 0.820 & 0.801 \\
\hline X4.3 & 0.859 & 0.801 \\
\hline X4.4 & 0.817 & 0.801 \\
\hline \multicolumn{2}{|c|}{ Sources deresed } \\
\hline
\end{tabular}

TABLE V.

VALIDITY AND RELIABILITY PHYSICAL EVIDENCE (X5)

\begin{tabular}{|l|l|c|}
\hline Item & Pearson Correlation & Alpha \\
\hline $\mathrm{X} 4.1$ & 0.570 & 0.807 \\
\hline $\mathrm{X} 4.2$ & 0.840 & 0.807 \\
\hline $\mathrm{X} 4.3$ & 0.859 & 0.807 \\
\hline $\mathrm{X} 4.4$ & 0.823 & 0.807 \\
\hline
\end{tabular}

Sources: data processed

TABLE VI. V VALIDITY AND RELIABILITY CUSTOMER SATISFACTION (Y1)

\begin{tabular}{|l|l|l|}
\hline Item & Pearson Correlation & Alpha \\
\hline Y1.1 & 0.633 & 0.814 \\
\hline Y1.2 & 0.850 & 0.814 \\
\hline Y1.3 & 0.873 & 0.814 \\
\hline Y1.4 & 0.830 & 0.814 \\
\hline \multicolumn{2}{|r|}{ Sources: deta procesed } \\
\hline
\end{tabular}

TABLE VII. V VALIDITY AND RELIABILITY EMPLOYEE PERFORMANCE (Y2)

\begin{tabular}{|c|c|c|}
\hline Item & Pearson Correlation & Alpha \\
\hline Y2.1 & 0,821 & 0,804 \\
\hline Y2.2 & 0,850 & 0,804 \\
\hline Y2.3 & 0,794 & 0,804 \\
\hline Y2.4 & 0,893 & 0,804 \\
\hline Y2.5 & 0,792 & 0,804 \\
\hline Y2.6 & 0,833 & 0,804 \\
\hline
\end{tabular}

IV. RESULTS AND DISCUSSION

A. Results

TABLE VIII. HYPOTHESIS TESTING RESULT

\begin{tabular}{|l|l|l|l|l|l|l|}
\hline \multicolumn{2}{|c|}{ Label } & Estimate & S.E. & \multicolumn{1}{c|}{ C.R. } & \multicolumn{1}{c|}{ P } \\
\hline Cust. Satisfaction & $<---$ & Reliability & .195 & .087 & 2.230 & $.026^{*}$ \\
\hline Cust. Satisfaction & $<---$ & Responsiveness & .141 & .149 & .947 & .344 \\
\hline Cust. Satisfaction & $<---$ & Guarantee & .446 & .115 & 3.884 & $.000^{*}$ \\
\hline Cust. Satisfaction & $<---$ & Physical Evidence & -.027 & .221 & -.122 & .903 \\
\hline Cust. Satisfaction & $<---$ & Empathy & .002 & .162 & .014 & .989 \\
\hline Employee Performance & $<---$ & Reliability & .169 & .075 & 2.255 & $.024 *$ \\
\hline Employee Performance & $<---$ & Responsiveness & .180 & .126 & 1.433 & .152 \\
\hline Employee Performance & $<---$ & Guarantee & .298 & .103 & 2.885 & $.004^{*}$ \\
\hline Employee Performance & $<---$ & Physical Evidence & .346 & .185 & 1.876 & .061 \\
\hline Employee Performance & $<---$ & Empathy & -.177 & .136 & -1.301 & .193 \\
\hline Employee Performance & $<---$ & Cust. Satisfaction & .270 & .084 & 3.204 & $.001 *$ \\
\hline
\end{tabular}

\section{B. Discussion}

Reliability has an effect on customer satisfaction of BPTSP. Responsiveness has no effect on customer satisfaction BPTSP. Guarantee has an effect on customer satisfaction of DKI Jakarta BPTSP; Physical evidence has no effect on customer satisfaction of BPTSP. Empathy has no effect on customer satisfaction BPTSP.

Reliability support DKI Jakarta BPTSP Performance. Responsiveness is not required for DKI Jakarta BPTSP Performance. Guarantees have impact on DKI Jakarta BPTSP Performance. Physical evidence does not conflict with DKI Jakarta BPTSP Performance. Empathy does not affect DKI Jakarta BPTSP Performance. Customer satisfaction agree with DKI Jakarta BPTSP Performance.

\section{CONCLUSION}

Reliability and guarantee have a positive and significant effect on customer satisfaction of DKI Jakarta BPTSP. Reliability and guarantee have a positive and significant effect on the performance of DKI Jakarta BPTSP. Customer satisfaction is also affecting to employee performance. The hypothesis is accepted, because employees must be deft before their superiors and enter in their performance appraisal. Performance assessment also includes how BPTSP employees

provide maximum service and have the willingness to serve (the community), also serve with honesty in serving and provide maximum service.

\section{REFERENCES}

[1] Z. Zeithaml, A. Vallarie, P. Parasuraman, A. Parsu and L. Berry, "Delivering Service Quality:Balancing Customer Perceptions and Expectations," Journal of marketing, 1990. New York: The Free Press.

[2] P. Kotler and K.L. Keller, Marketing Management. Global Edition, Pearson Prentice Hall, 2012.

[3] V.A. Zeithaml, L.L. Berry and A. Parasuraman, "The behavioral consequences of service quality," Journal of marketing, vol. 60, no. 2 , pp. 31-46, 1996

[4] W. Mulyati and R. Kristaung, "Implikasi humor dan peran layanan karyawan garis depan terhadap kepuasan pelanggan,” Jurnal Manajemen dan Pemasaran Jasa, vol. 10, no. 2, pp. 249-266, 2017.

[5] R.M. Bakar, Z.F. Damaran and A.Y. Mansyur, "Post-service recovery emotion and customer trust: The role of satisfaction as mediation," Jurnal Manajemen dan Pemasaran Jasa, vol. 13, no. 1, pp. 17-28, 2020.

[6] S. Setyowati, Rr Dyah Eko, Y. Antariksa and K.A.S. Dewi, "Analysis of The Effect of Physical Evidence, Reliability, Responsiveness, Assurance, Emphaty, toward Customer Satisfaction Lotte Mart in Jakarta Indonesia," Proc. Of the second Intl. Conf on Advances in Economics, Management and Social Study - EMS, 2014. Malaysia 